\title{
Subjective Well-Being and Conflicting Social Identities in the Frontier Regions of Russia
}

\author{
Anna V. Nemirovskaya \\ National Research University Higher School of Economics \\ Moscow, Russian Federation
}

Received 10.05.2020, received in revised form 20.08.2020, accepted 04.09.2020

\begin{abstract}
This study analyses how subjective well-being indicators and territorial social identities vary in the Russian frontier and core regions. It is assumed that the frontier history of settlement and border location of the regions has an impact on various sociocultural and socio-political features of its communities, thus shaping the specific territorial social identities of people living on the front lines of Russia. These identities might be in conflicting relations, especially when taken as a factor for shaping specific public attitudes and moods, in particular, satisfaction with life. Based on the surveys in four border, or frontier and two central, or core, regions, conducted in 2016 (total $\mathrm{n}$ of respondent $=$ 5000), the paper presents an explanatory model for life satisfaction in a comparative aspect, where different factors of socio-economic, socio-demographic, psychological, attitudinal, and cultural nature are considered. The impact of different territorial social identities on life satisfaction in the frontier and central regions was revealed. For both groups of the regional samples, the assessment of the state of affairs in the region, and the country as well, demonstrated a stable positive effect on life satisfaction, as well as the factors of locus of control, income group, and economic optimism. The predictor of social cohesion appeared to be significant only for frontier regions of Russia, in line with the classical concepts of the frontier. At the same time, age and religiosity factors predicted life satisfaction in the core regions only. This study contributes to the research on the border and frontier areas, as well as regional specifics of Russian regions, representing it as a vast and heterogeneous in terms of socio-cultural and socio-economic division country.
\end{abstract}

Keywords: subjective well-being, life satisfaction, territorial identity, Russian regions, frontier.

The study was supported by a grant from the Russian Science Foundation: project No. 1818-00341 "Value transformation and subjective quality of life: a regional perspective". The study used empirical materials of the research project "Russian frontier: civil identity at the forefront country", carried out with the participation of the author of this paper, by the autonomous non-profit organization "Sociological Workshop of Zadorin" (Research

\footnotetext{
(C) Siberian Federal University. All rights reserved

* Corresponding author E-mail address: annanemirov@hse.ru ORCID: 0000-0003-2013-0964
} 
group ZIRCON) with targeted funding, allocated by the non-profit foundation "Institute of Social-economic and Political Research".

Research area: sociology.

Citation: Nemirovskaya, A.V. (2020). Subjective well-being and conflicting social identities in the frontier regions of Russia. J. Sib. Fed. Univ. Humanit. Soc. Sci., 13(9), 1541-1558. DOI: 10.17516/19971370-0662.

\section{Introduction}

This paper considers subjective well-being and the social identities of the population of five regions, which, according to their socio-historical, territorial-geographical, and settlement characteristics, belong to the contemporary frontier of Russia. Historically developed socio-cultural uniqueness and the strategic geographical location of the frontier regions of Russia, an example of which in this study are the Crimea, the Primorsky Territory, the Kaliningrad and the Murmansk regions determines the importance of their study in the light of country's socio-economic development, national security and migration. Frontier regions act as an arena of confrontation between different types of identities (local, regional, all-Russian, cosmopolitan, patriotic, independent, and so forth) and in the event of a decline of the general national type of identity and the prevalence of exclusively local, regional or separatist ideological discourse, these regions might become potentially "weak links" and sources of possible conflicts, as well as subjects of manipulation for different political forces.

For this reason, the subjective well-being in general and life satisfaction in particular of the population living in the geostrategic territories of Russia, remote from the federal center, and bordering with other states, are essential parameters for assessing public moods in the region, including the factor of possible outbound migration of the regional population. Not only the specificity of the geographical location and the history of the settlement of the frontier territories have an impact on the socio-cultural features of the population. In turn, public attitudes, hypothetically, can also act as one of the factors influencing the degree of "frontier self-perception," including the identity of the population living on the "frontlines" of Russia. In this context, considering life satisfaction and subjective well-being as essential aspects of public moods, it is necessary to analyze its various indicative parameters for the population of the frontier regions, as well as their ideas about the state of affairs in the region of residence and the country.

These regions can conventionally be viewed as the Southern, Eastern, Western and Northern frontiers - territories of specific socio-economic conditions associated with more intensive cross-border communication and increased influence of various neighboring "frontier" states and cultures (Turkey, Japan, China, Eastern, Central, and Northern Europe). In an interdisciplinary sense, the term frontier is applicable to the study of border regions of Russia, since it is not just a spatial metaphor, which stands for discovery and advancement, but also includes the meaning of a place that is facing an expansive force of various nature, varying from the dominance of foreign neighborhood to political regimes, or global socio-economic phenomena (Imamura, 2015). In this study, the understanding of the term "frontier" differs from the classical one introduced by Frederick Turner (Turner, 1920). We focus more on the aspect of "borderland" and neighboring, rather than on development, or reclaiming, or conquering, guided, among other things, by Turner's comment that "Russia needs its concept of interpreting the development of its frontiers."

Following the concept of Frederick Turner (Turner, 1920), we may assume that the borderline geographical position, as well as the his- 
tory of the settlement of frontier regions and their current socio-economic conditions, leave their imprint on the social relations, value orientations, attitudes, and identities of the population living on the "frontiers" of Russia. "The people of the frontier" in many characteristics contrast with the inhabitants of the regions of the central part of Russia, for example, in such socio-cultural traits as higher initiative, independence, entrepreneurship, the ability to rely on their capabilities, and not on help from the state, and others. According to the frontier theory, the typical properties of the identity of a resident of the frontier also include openness to the outside world, readiness for a certain external expansion, initiative, and independence in decision-making (Turner, 1920). It is expected that frontier location manifests in a specific territorial identity of the population of such regions. For instance, it may result in more pronounced features of a local, or regional identity, which can prevail over a general federal identity, and also differ from territorial identity attitudes in the inner regions of Russia. Therefore, this paper is focused on the study of the territorial identity of the population of the border, or frontier territories, and its influence on their life satisfaction, in comparison with inner, central, or core geographical areas of Russia.

\section{Theoretical framework}

According to E. Diener, subjective well-being is a complex psychological phenomenon, comprising of several distinct, but closely related constructs of cognitive evaluations and emotional experiences (Diener et al., 1999). Subjective well-being is made up of two components, one referring to the emotions, moods, and feelings (affective balance) and another denoting quite stable, cognitive measures of general judgments about satisfaction with life and satisfaction with specific life spheres like family, work, leisure and others (life satisfaction). In this study, it is assumed to consider a person's self-assessment of his life as a whole, as an integral characteristic, which largely depends on the conditions of the living environment, the socio-economic situation in the region of residence. The affective component expressed in the assessment of one's near future will also be analyzed. Since the psychological traits closely associated with subjective well-being (DeNeve, Cooper, 1998; Tay et al., 2014; Dolan et al., 2008), this study will also consider the locus of control, that is an extent to which individuals believe that they can control events that affect them and the religiosity, which fulfills the needs of a person. Previous studies also find a significant positive effect of having children on life satisfaction. However, when controlling for other circumstances that can be relatively negative, e.g., family composition and income level, the factor of having children seem to be an additional challenge to well-being (Dolan et al., 2008).

Social identity is of fundamental importance for personal well-being (Dovidio et al., 2005), an affective attachment to social identities, such as identification with one's nation-state, especially in a civic sense, fosters subjective well-being (Reeskens et al., 2010). Individuals develop identifications with different communities, varying geographically from local to the nation, or world scale. The territorial dimension of social identity can be defined as a sense of belonging and loyalty to a community of some area that is formed when individuals categorize themselves as members of a particular country, region, or place of residence. For instance, regional identity is grounded in the regional history, in the geographical location and surrounding landscape, and a variety of socio-cultural features. It can be seen as a part of self-identity and is, therefore, the personal attachment to a region, shaping a positive feeling of a collective towards a region or formed by a region (Pohl, 2001). Similarly, national and local territorial identities reflect the positive attitude to the country of the whole or the place of residence, to which an individual has an emotional attachment and forms various personal associations and opinions. Social attitudes and perceptions of the regional population are the primary socio-cultural factors affecting socio-cultural, economic, and political processes in the country. Among their most important forms are the views of residents about their region, about Russia as a whole, about federal and regional authorities (Nemirovsky, 2013). It can be assumed that the socio-cultur- 
al and historical characteristics of the respondents' place of residence have an impact on the perception of the region, country, and place of residence. For instance, the study the image of Russia in eight border regions of the Urals, Siberia and the Far East revealed a controversial image of a country: the positive features are related to the international prestige of Russia, its historic achievements and cultural heritage, while the negative ones are determined by the low standard of living, social inequality and the imperfection of the economic system (Maksimova, Morkovkina, 2017). The authors point out that the opinion of the respondent from the border regions of the country may differ significantly from the views of the inhabitants of the internal territories of Russia. Based on regional survey data, it was also revealed that feelings of pride in the country are also associated with attitudes towards faith: non-believers are less inclined to be proud of their country (Maksimova et al., 2015).

People form a regional community by producing and reproducing social cohesion by their practical consciousness and actions (Pohl, 2001). Social cohesion, impacting subjective well-being, has strong similarities as a concept with social capital. However, it focuses more on the importance of shared values, generalized trust, attitudes, and relationships among members of society (Klein, 2013). Similarly, social capital also makes an important contribution to the subjective well-being of a person, representing networks of social relations formed based on social interaction and trust, that provide individuals with the resources for cooperation. In addition, correlations were revealed between the respondent's social capital and their locus of control (Guzhavina, 2019). In the frontier territories, the experience of settlement, as well as living in the distance from the state authorities, are conducive to the formation of norms of community solidarity and cooperation. Using the World Value Survey's data in Russia, the USA, Canada, and Brazil, it was found that higher level of social capital, expressed in voluntary activity, social trust, tolerance of outgroups, and civic protest is a distinctive feature of modern frontier life in general (Foa, Nemirovskaya, 2019).
Another significant factor affecting subjective well-being is wealth (Diener et al., 1995) since it allows a person to achieve their life goals and enhance their social position. In other words, material well-being leads to an increase in subjective well-being primarily through the realization of primary physical needs (Veenhoven, 1991). However, the wealth or income level does not have a long term effect on subjective well-being and is efficient in the case when the basic needs of a person are not satisfied. Generally, people tend to adapt to their income level (Easterlin, 1974), and its impact on subjective well-being decreases. When a certain level of subjective well-being is reached, the importance of post-materialistic values increases (Inglehart, 1990). However, we have to assume regarding most Russian regions that the standard of living of the population has not yet reached a high level. At the same time, the differentiation in income continues to be is very high. For this reason, following the Maslow's hierarchy of needs (Maslow, 1954), when sufficient income gives advantages in terms of basic needs, security, and the realization of one's abilities, in this study, we consider not only a financial situation of the respondent "How would you estimate the current economic situation of your family?"), but also use another indicator for the self-assessment of the financial capabilities of a person in accordance with their needs and income level ("Which of the following groups in terms of living standards would you most likely attribute yourself to?"). What is more, such an indicator also serves as a socio-economic identity, as it implies either the respondent's idea of their consumer capabilities and reveals the level of deprivation of needs, and also allows to locate a person in the economic stratification of the region.

\section{Statement of the problem}

In line with the abovementioned reasoning, we proposed several hypotheses to test in this research:

1) Territorial identity as an indicator of attitude towards people's immediate socio-cultural environment will have an impact on their subjective well-being. In particular, national, regional and local identities as factors of sub- 
jective well-being of a person will act in different ways in the center and on the frontier of the country, since the residents of the frontier may have a more prominent local and state patriotism, a strong identification both with their place of residence and the country as the whole, considering themselves true representatives of their state on its borders.

2) In the case of prevailing national territorial identity, life satisfaction will be higher. In contrast, the dominant regional or local identities may come into conflict with a person's ideas about their country, its economic situation, governance institutions, and thus contribute to a feeling of dissatisfaction.

3) In turn, a favorable assessment of the state of affairs in the region and the country will have a positive effect on subjective well-being in general and satisfaction with life in particular, since people do not exist outside their regional and country socio-cultural environment and assesses their life course, achievement, and their social position according to the regional and national context.

\section{Methods}

This paper is based on analyzing the data of the initiative research project «Russian Frontier: Civic Identity at the Frontline of the Country" was implemented in collaboration with ZIRCON Research Group using targeted funds allocated by a non-profit foundation. The contributor is one of the developers of the design and methodology of this study, as well as the co-author of the analytical report based on the results of this research project. The study was aimed at studying the Russian frontier regions, specifically identifying the presence/absence of differences in social identities, cultural and political attitudes, social capital, and life satisfaction of the population of the Russian "border" and "internal" regions.

The fieldwork was conducted in September - December 2016 in 6 Russian regions. The empirical study was carried out in four frontier regions - the Republic of Crimea (more precisely, in the united Crimean region - the Republic of Crimea and the city of Sevastopol), the Primorsky Territory, Kaliningrad and Murmansk regions, as well as in two control regions located in the inner part of the Russian Federation - Kostroma region and the Republic of Chuvashia. The sample size is 1000 respondents in each frontier region and 500 respondents in each control region. In total, 5000 people were surveyed. The sample represents the adult population aged 18 and older of each of the six regions in terms of gender, age, education, type of place of residence (the type of settlement). Surveys were implemented by the method of personal interview (face-to-face) at the place of residence of the respondent.

Regarding the empirical technique, we adopt the methods of descriptive statistics and OLS regression for explaining life satisfaction in the frontier and the core regions. For regression modeling, the sample was divided into two parts, each comprising of four frontier regions and two core regions, respectively.

The dependent variable is general life satisfaction, measured with "How satisfied are you with your life as a whole these days", a 4-point scale, where one means "absolutely dissatisfied", while five is "absolutely satisfied".

The independent variables include:

- national, regional and local territorial social self- identification (measured with a question "Who do you personally consider (feel) yourself first of all?");

- social cohesion as an indicator of social capital ("Do you think there is more agreement, solidarity or disagreement, disunity among people in your region today?" with a 4-point scale, where one stand for "obviously disagreement and disunity" and 4 - "definitely agreement and solidarity");

- religiosity ("Do you consider yourself a believer," 1 - yes, $0-$ no);

- locus of control ("At present, on what your (your family) financial situation depends to a greater extent: on you - on your efforts, qualifications, will, or on external reasons beyond your control (situation in the country, the world, a coincidence of circumstances, luck, bosses and so forth)? with a 5-point scale, where one means "mostly due to circumstances beyond my control" and 5 "mostly depends on me");

- income group as the self-assessment of the household's consumer status ("Which 
of the following groups in terms of living standards would you most likely attribute yourself to?", with a 5-point scale, where one stands for "We can barely make ends meet. There is not enough money even for food" and 5 - "We can afford quite expensive things - an apartment, a summer residence and much more").

- economic optimism ("In a year from now, you (your family) will live better than now, worse or the same as now?", with a 5 -point scale, where one is "much worse" and five is "much better");

- satisfaction with the state of affairs in the region ("Are you satisfied or not satisfied with the state of affairs in the region?", with a 5-point scale, where one means "absolutely dissatisfied", and five is "absolutely satisfied");

- satisfaction with the state of affairs in the country ("Talking about Russia as a whole, are you satisfied or not satisfied with the state of affairs in the country?", with a 5-point scale, where one designates "absolutely dissatisfied", and 5 - "absolutely satisfied")

Independent variables also include several controls such as age, gender, number of children in the family, and type of settlement $(1$ - rural settlement, 7 - city with more than 1 million inhabitants).

\section{Discussion}

We consider the social well-being of the population of the frontier and control regions using several traditional indicators: general life satisfaction, economic optimism (measured as the expectations regarding the near future), and the current self-assessment of the family's consumer status. The comparative analysis of life satisfaction demonstrates the visible differentiation between the studied regions (Fig. 1). The four frontier regions show especially noticeable results: the percentages of respondents who declare a certain degree of satisfaction with their current life (in the aggregate of the replies, the "quite" and "rather" satisfied) differ by almost 20 pp: if in Crimea and the Murmansk region such replies accounted for three-quarters of the population (76-77\%), then in the Kaliningrad region and the Primorsky Territory - only $55 \%$ and $58 \%$, respectively. As for the control regions, the share of respondents declaring their satisfaction with their life is lower than in Crimea and the Murmansk region, but higher than in the Kaliningrad region and the Primorsky Territory: $65 \%$ in the Kostroma region and $70 \%$ in the Chuvash Republic.

Needless to say, satisfaction with life is determined by a combination of factors of different nature; nevertheless, the material factor probably plays a major role. Hence, the respondents were asked to assess the current level of their financial situation and the consumer status of their families. In all six regions of the study, the majority of respondents (from $56 \%$ to $65 \%$ ) estimated the financial situation of their house-

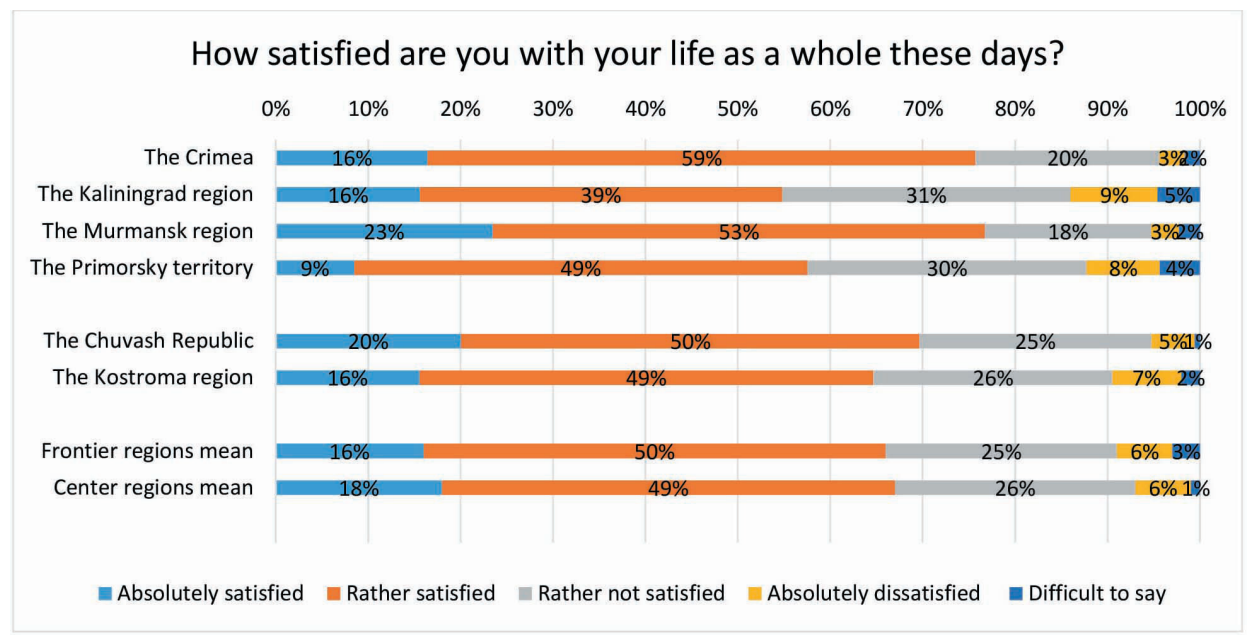

Fig. 1. Life satisfaction, 2016 
holds as "average". That is why the ratio of the shares of positive and negative assessments is more informative for the analysis. Only in two regions, which are Crimea and Murmansk region, the share of positive assessments of the household's financial situation prevails over the share of negative ones. Recall the satisfaction with life is also the highest in these regions. On the contrary, in the remaining four (two frontier and two core) regions, the ratio is opposite, i.e., the share of negative assessments is higher: 1.8 times (Kostroma region), 1.5 times (Kaliningrad region and Chuvash Republic), 1.3 times (the Primorsky Territory).

The socio-economic identity is analyzed using the self-assessment by the population of six regions of the household's consumer status, reveals both similarities and differences (Fig. 2). Among possible alternatives, respondents from every region most often chose the middle option "There is enough money for food and clothes. However, buying durable things is difficult for us." Nevertheless, the differentiation is quite noticeable, for instance, $62 \%$ of the respondents from Crimea chose the "average" option, and only $45 \%$ of survey participants from the Chuvash Republic do the same. The ratio of the shares of groups with low and high consumer status (the former includes the cumulative share of answers "We are barely making ends meet. There is not enough money even for food" and "There is enough money for food, but buying clothes causes financial difficulties", the second comprises of the cumulative share of answers "We can easily acquire durable things. However, it is difficult for us to acquire costly things" and "We can afford quite expensive things - an apartment, a summer residence and much more") in almost all regions is in favor of the former, except for the Primorsky Territory, where even a minimal preponderance of high ratings can be observed. Especially noticeably, the share of citizens who assess the consumer status of their family low exceeds the share of citizens with high ratings in the Kaliningrad and Kostroma regions and Crimea as well (2.3-2.4 times). In the Murmansk region and the Chuvash Republic, the gap is not so high and amounts to 1.3 and 1.5 times, respectively.

Thus, negative trends in self-assessments of the household's financial situation are most consistent in the Kaliningrad and Kostroma regions. The self-assessments of the population of the Murmansk Region and the Primorsky Territory, on the contrary, in both cases look slightly higher or at the average level. The replies of the respondents from Crimea and the Chuvash Republic are less consistent. The Crimeans exhibit rather high self-assessments

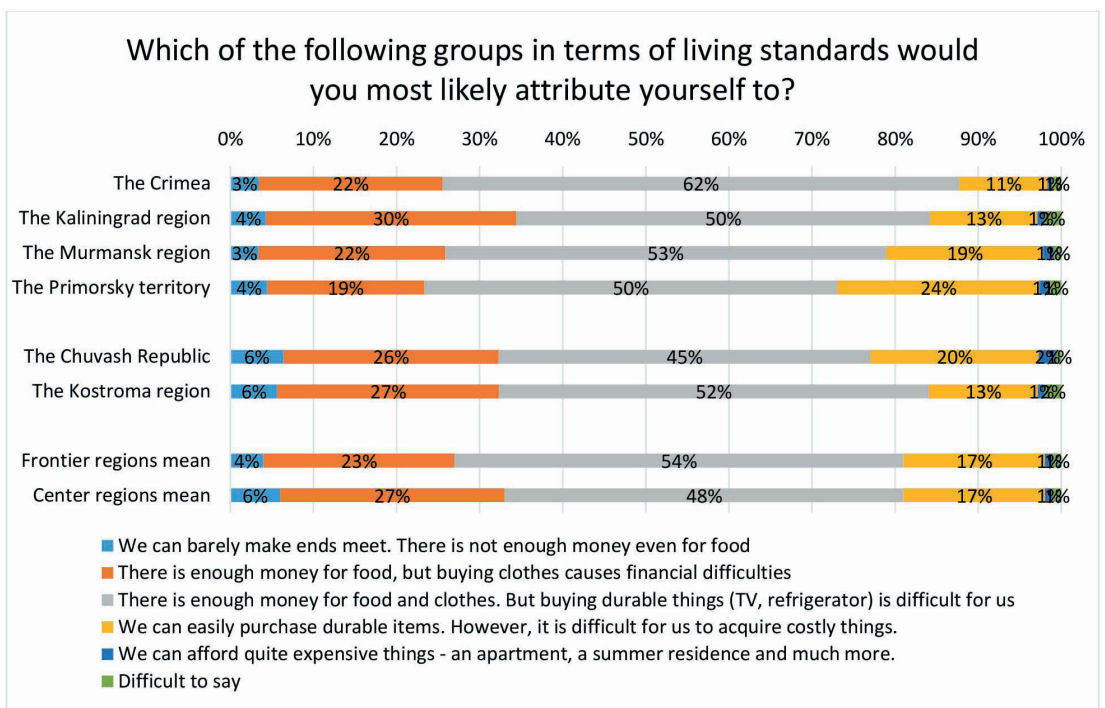

Fig. 2. The self-assessment of the household's consumer status as socio-economic identification, 2016 
of the family's financial situation at the general level, but the self-assessments of consumer status are, on the contrary, rather low. Probably, the inconsistency of the assessments is affected by the ambiguity of the processes in the Crimean economy and the financial support of citizens (the growth of pensions, salaries for specific categories of citizens, the extension of support to residents in the form of maternity capital with a simultaneous increase in prices). Assessing their financial situation, the respondents from the Chuvash Republic more often than others chose the option "average". However, in self-assessments of the household's consumer status, on the contrary, the average answer alternative was indicated most rarely. However, in terms of the ratio of negative and positive assessments in both cases, the results are the same.

The analysis of the survey of the regional population revealed the territorial differentiation in the expectations of the population from the near future (economic optimism) (Fig. 3). According to the survey data, the most optimistic today are the residents of Crimea. Here, only $6 \%$ of citizens expect a deterioration in the life of their families in a year, which is at least half as less as in other studied regions. Besides, Crimea has the highest share of optimists (32\%). Most likely, a relatively significant part of the respondents remains euphoric about joining Russia, which affects the nature of their expectations. In three other regions, the excess of the share of optimistic expectations over the share of pessimistic ones can be noted: Murmansk Region, the Primorsky Territory, and the Chuvash Republic.

The least optimistic expectations are reported in Kaliningrad and Kostroma regions. Low self-assessments of the material situation were also recorded in these regions, as well as a low level of life satisfaction in the Kaliningrad region. The share of respondents from the Kaliningrad region, declaring negative expectations about their future, is significantly higher than in the other five regions and accounts for more than a quarter of survey participants (28\%). Moreover, there are fewer optimists than pessimists $(23 \%)$ only in the Kaliningrad region too. Perhaps the expectations of the residents of the Russian exclave are relatively more alarming than the expectations of residents of other regions of the country due to current international geopolitical pressure. Interestingly, the prevailing opinion about the near future was not observed in the Kostroma region: optimistic and pessimistic answers distributed almost in equal shares (15\% and $14 \%$, respectively), and a significant majority of citizens either do not expect any changes $(52 \%)$ or find it difficult to predict the future $(19 \%)$.

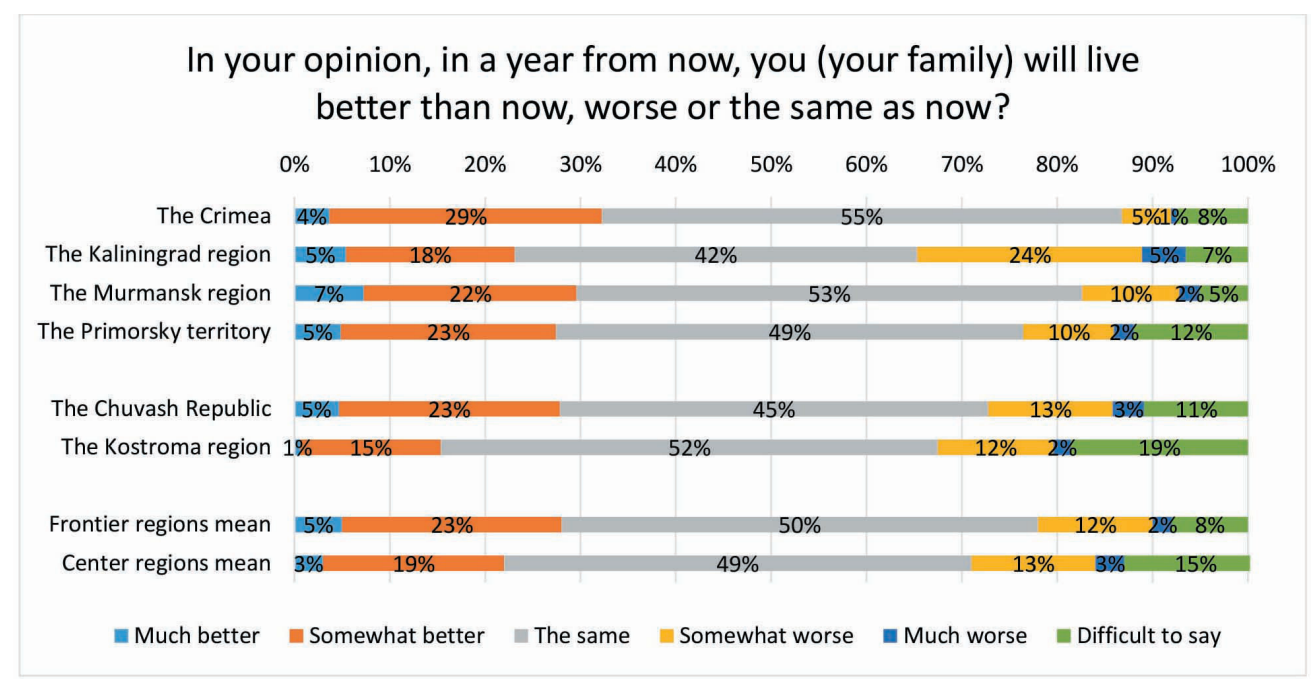

Fig. 3. Economic optimism, 2016 
To sum up, according to the mentioned above indicators of the social well-being, the self-assessments of the population of two regions, the Kaliningrad and Kostroma regions, are the least favorable. Apparently, this phenomenon has different grounds, including an essential factor for the Russian exclave influencing self-esteem is its geographical location, proximity to European countries, which sets high standards for comparison. Comparatively, more favorable self-assessments of social well-being were recorded in Crimea and the Murmansk region. Accordingly, the social well-being of the population in the Chuvash Republic and the Primorsky Territory has got average scores for the six regions of the study.

The assessment of the state of affairs in the region of residence plays a vital role in the subjective well-being of an individual since the region is the closest socio-cultural environment that determines the level and quality of life of people, and in which their life plans are realized. The degree of satisfaction of the population of the studied regions with the situation in the region of their residence is highly differentiated (Fig. 4). The share of respondents who expressed satisfaction with the situation in the region ranges from $18 \%$ (in the Kostroma region) to $51 \%$ in the Crimea, i.e., differs almost threefold. Crimea is mainly distinguished by high assessments of the state of affairs in the region since there is the lowest share of neg- ative assessments (only 7\%). The worst of all, the situation is presented in the assessments of the population of the two control regions of the study, the Kostroma region, and the Chuvash Republic. In both of these regions, the share of residents who expressed dissatisfaction with the situation in the region of residence is significantly higher than the share of those who gave affirmative answers. As for the frontier regions, in terms of the level of satisfaction with the state of affairs in the region, they surpass the Kostroma region and the Chuvash Republic but are inferior to the Crimea. In these three regions, the assessments of the residents are very heterogeneous; there is virtually no prevailing opinion.

The well-being of people and their assessment of their lives and perspectives cannot be studied in isolation from the broader socio-cultural and economic situation, their perception of the state of affairs in the country where they live. In general, the indicators of satisfaction with the situation in the country in the studied regions hardly look optimistic, but, at the same time, they are far from the critical threshold. The results of the survey demonstrate an uncertain or cautious position of the majority of the respondents in all the regions (Fig. 5). The extreme points of view, such as "completely satisfied" and "completely dissatisfied" are present in the overwhelming minority (only $3-5 \%$ each). A moderately restrained position

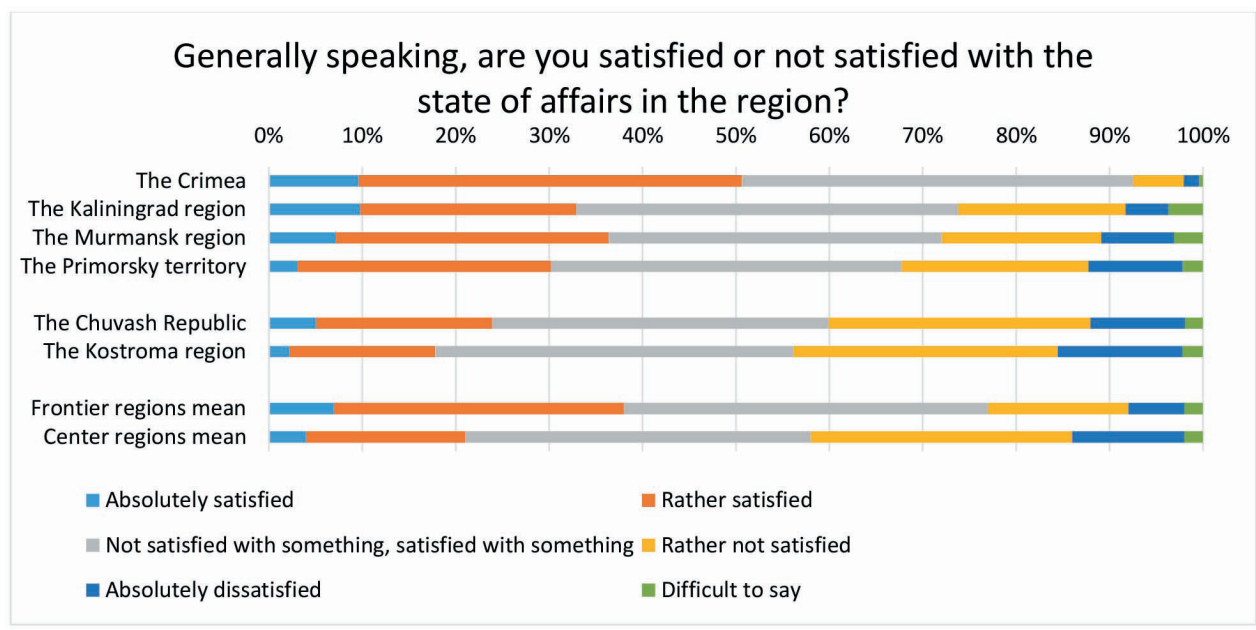

Fig. 4. Satisfaction with the state of affairs in the region of residence, 2016 


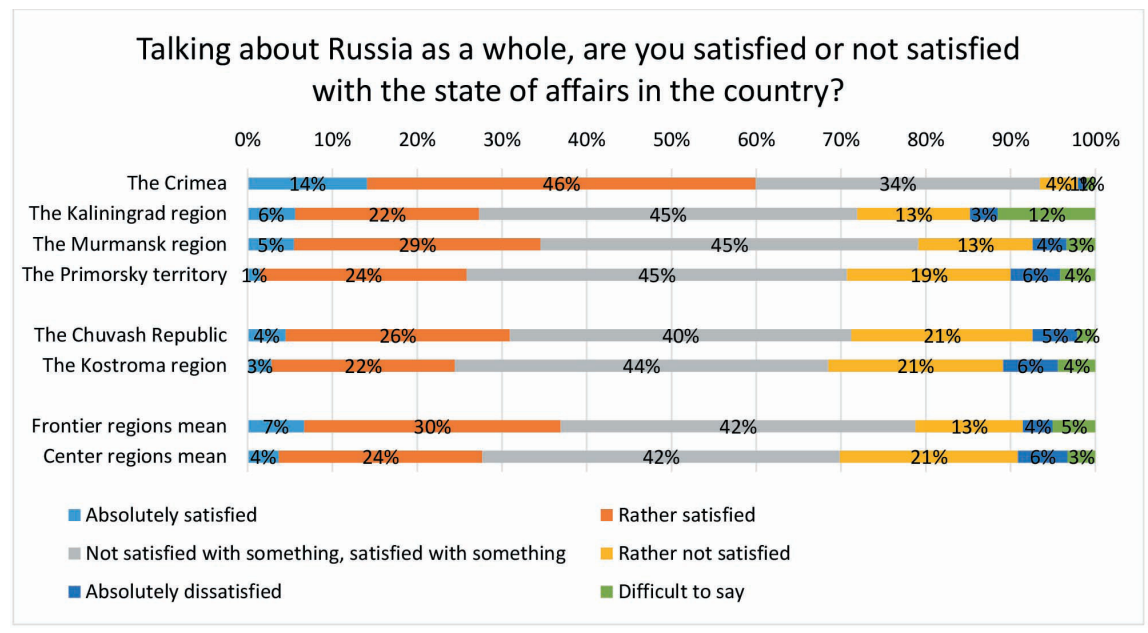

Fig. 5. Satisfaction with the state of affairs in the country, 2016

prevails, since about $45 \%$ of the respondents chose the answer "in some ways satisfied, in others not".

Still, the range of responses is slightly biased towards the positive: the number of replies "rather satisfied" is one and a half to two times higher than "rather dissatisfied". Among the frontier regions, Crimea stands out in terms of the share of positive-minded residents, where the favorable assessments prevail. There are two times more of them than in the rest of the frontier regions and control regions as well. The negative assessments are not at all popular with Crimean respondents. In the Kaliningrad region, there is a high proportion of respondents who found it difficult to answer $(12 \%$ vs. $2-4 \%$ for the rest of the regions), which means that they are undecided in their assessments or are cautious. The Primorsky Territory is the closest to the core regions among all frontier regions in terms of the assessment of the state of affairs in the country. The share of average ratings here is about the same as in other regions, e.g., the shares of those satisfied and dissatisfied with the state of affairs in the country, as well as in the control regions, are practically equal here.

To determine the territorial identity of the population, more specifically, how respondents identify themselves as members of different territorial communities, the instruments of regional surveys included questions to measure the respondents' identity, understood as referring themselves to one of five types of identities: local-territorial, regional, national (state), international, and cosmopolitan (meta-national). The analysis of the results obtained demonstrates a noticeable differentiation between some regions (see Table 1).

First of all, three regions with a similar type of territorial social self- identification should be noted: two frontier regions (Kaliningrad and Murmansk regions) and one core region (Chuvash Republic). The prevalence of country or national identity distinguishes these regions: the majority of respondents $(57-60 \%)$ consider themselves, first of all, "Russians, citizens of Russia." Attention is drawn to the fact that the prevalence of national identity in the Kaliningrad and Murmansk regions is combined with a high proportion of non-indigenous residents. It becomes evident that for those who have arrived from other regions of the country and have connections with them, it is more natural to consider themselves a part of the whole country than to associate themselves with a specific region. Other types of territorial identity are also represented in these three regions in close proportions: regional identification or identity with the region of residence is characteristic of $10-11 \%$ of residents in each of the three regions mentioned above. Local identification, or identity with the settlement of residence, is more widespread (22-25\%). 
Table 1. The territorial identity of the respondents, 2016

\begin{tabular}{|c|c|c|c|c|c|c|c|c|}
\hline \multicolumn{9}{|c|}{ Who do you personally consider (feel) yourself first of all? } \\
\hline & 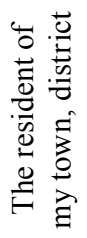 & 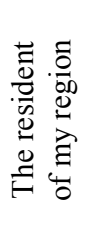 & 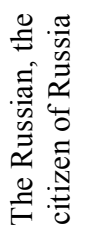 & 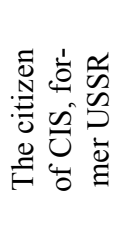 & 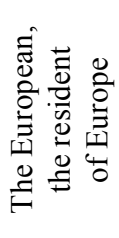 & 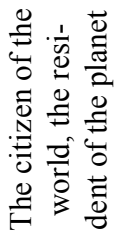 & $\frac{\dot{\Phi}}{\stackrel{\Xi}{0}}$ & 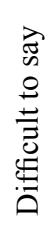 \\
\hline The Crimea & $16 \%$ & $35 \%$ & $41 \%$ & $3 \%$ & $1 \%$ & $3 \%$ & $0 \%$ & $1 \%$ \\
\hline The Kaliningrad region & $24 \%$ & $10 \%$ & $60 \%$ & $2 \%$ & $1 \%$ & $2 \%$ & $0 \%$ & $1 \%$ \\
\hline The Murmansk region & $22 \%$ & $11 \%$ & $57 \%$ & $5 \%$ & $1 \%$ & $4 \%$ & $0 \%$ & $1 \%$ \\
\hline The Primorsky territory & $30 \%$ & $20 \%$ & $41 \%$ & $2 \%$ & $1 \%$ & $2 \%$ & $0 \%$ & $3 \%$ \\
\hline The Chuvash Republic & $25 \%$ & $10 \%$ & $58 \%$ & $2 \%$ & $0 \%$ & $4 \%$ & $0 \%$ & $1 \%$ \\
\hline The Kostroma region & $44 \%$ & $9 \%$ & $42 \%$ & $2 \%$ & $0 \%$ & $2 \%$ & $0 \%$ & $1 \%$ \\
\hline Frontier regions mean & $23 \%$ & $19 \%$ & $50 \%$ & $3 \%$ & $1 \%$ & $3 \%$ & $0 \%$ & $1 \%$ \\
\hline Center regions mean & $34 \%$ & $9 \%$ & $51 \%$ & $2 \%$ & $0 \%$ & $3 \%$ & $0 \%$ & $1 \%$ \\
\hline
\end{tabular}

Each of the three other regions in this research (the Primorsky Territory, the Kostroma region, and the Crimea), show their peculiarities in terms of the territorial identity of their residents. The only feature in common is relatively low, as compared to the other regions in the study, level of national self-identification (41-42\%, less than half of the respondents). Along with the reduced expression of national identity, the highest level of local identity is observed in the Kostroma region, where 44\%, or almost half of the surveyed residents, tend to identify themselves with the settlement, which makes this region stand out from others. Regional and other types of identities are much less common there. As for the Primorsky Territory, the level of local identity (30\%) is lower than in the Kostroma region but is higher than in other regions of the study. However, in contrast to the Kostroma region, about every fifth respondent from the Primorsky Territory said that they consider themselves to be a resident of their region (expressed regional identity). The local and regional identity in a Far Eastern region can be shaped by many factors, among which are the geographic remoteness of the region from central Russia, the positioning of the region as a unique and strategically significant territory for interaction with the Asia-Pacific Region, the feeling of being "on the edge of the earth." All these produce the awareness of belonging to one's city/village or the region of residence than the awareness of belonging to the country to most of the surveyed inhabitants.

Crimea is a separate unique case since this is the only region out of six in which regional identity is more salient than the local one; here, the level of regional identity is generally the highest $-35 \%$. Probably, it is explained to a certain extent by the current situation, the entry of Crimea into the Russian Federation, and the change of the citizenship of its inhabitants, which entails a shift in identity. The enhanced regional identity might be an expression of a way of adapting to socio-political changes. Besides, Crimea as a peninsula is a geographically integral object, and it is perceived in this way, as a holistic, independent region. What is more, the regional identity, the feeling of being "a true Crimean" is today a factor mobilizing most of the region's population.

According to the survey, the other types of territorial identity, international and cosmopolitan (meta-national) ones, are not widespread. No more than $1 \%$ of the respondents consider themselves "Europeans", even in the Kalini- 
grad region, which is geographically close to Europe. Only $2-3 \%$ of respondents identify themselves as the residents of the CIS or the countries of the former USSR, which are the values within the statistical measurement error. The only exclusion is the respondents of the Murmansk region, who provide this reply a bit more often (5\%). Similarly, the identity "a citizen of the world, an inhabitant of planet Earth": it is chosen only from $2 \%$ to $4 \%$ of respondents in different regions.

It is also worth noting the influence of the material factor on the territorial identity. The representatives of groups with high and middle incomes more often identify themselves as "citizens of Russia, first of all" than low-income categories of the population.

The respondents were also asked about their religiosity and religious identity, which is not only one of the primary social identifications of a person, but also an essential factor for their subjective well-being. The survey included two questions: Do you consider yourself a believer and, if yes, what religion do you adhere to? There are apparent differences concerning this type of identity in the Primorsky Territory; the situation is more or less similar in other regions, where the majority of respondents - from $67 \%$ to $73 \%$ - identify themselves as "Orthodox Christians". It is essential to notice that the proportion of those who go to church is much lower, as this indicator serves mostly as a cultural identity. The percentage of residents who define themselves as "Orthodox Christians" is noticeably smaller in the Primorsky Territory (46\%). At the same time, this region is distinguished by a relatively high proportion of atheists (34\%), which is twice or even three times higher than in other regions. There is also the highest proportion (16\%) of those who declare that they do not belong to a particular confession. It might be assumed that one of the reasons for the high proportion of non-believers in the region is the influence of the proximity of eastern countries and the absence of deep Christian roots, compared to the central part of Russia. It should be added that Crimea also stands out in religious identity, but regarding the share of Muslims, mainly due to the Crimean Tatar population. The percentage of Muslims in the Chuvash Republic is slightly higher than in other regions, except Crimea, and also partly due to the Tatars living here.

\section{Explaining life satisfaction}

In order to test hypotheses, separate regression models for the frontier and central regions have been built (Table 2). The indicators of territorial identity were introduced into the regression models only independently since they are in strong negative correlation with each other. What is important, the correlation coefficients between local and national identities are higher in the sample of the central regions (Phi Cramer's V is equal to $-0,737$ ), than in the frontier regions' sample $(-0,556)$. As for the local and regional identities correlation, the results are almost equal in both samples, $-0,235$ for the center and $-0,269$ for the frontier. As for the correspondence between regional and national identities, the center's coefficient scores $-0,330$ and the frontier's coefficient accounts for $-0,491$. So we may conclude that the divergence between local and national identities is even higher than between the regional and national ones. All these make it even more interesting to see how different territorial identity factors contribute to the life satisfaction of the inhabitants of two types of regions.

It is important to note that self-identification as a citizen of a country affects life satisfaction only in the regions of the frontier (models $1,4,7$, and 10 in table 2), not to mention the high significance of this factor. Interestingly, regional identity is significant only for the sample of regions of the frontier, while its influence on life satisfaction is negative (models 5,8 , and 11). It must be noted that the significance of regional identity appears only when predictors of satisfaction with the state of affairs in the region and country are introduced to the model. Likewise, local identity also evinces in the explanation of life satisfaction only in the frontier regions, while showing persistent negative influence across all models.

Regression modeling confirmed that regional and country-wide socio-economic contexts are essential for individuals' well-being. Thus, the satisfaction with the state of affairs in their region (models 4-9) and with the state of 
Table 2. Regression models 1-12 explaining life satisfaction in the frontier and central regions of Russia

\begin{tabular}{|c|c|c|c|c|c|c|}
\hline $\begin{array}{l}\text { a) Life satisfaction } \\
\text { dependent variable) }\end{array}$ & \multicolumn{2}{|c|}{ Model 1} & \multicolumn{2}{|c|}{ Model 2} & \multicolumn{2}{|c|}{ Model 3} \\
\hline 1 & \multicolumn{2}{|c|}{2} & \multicolumn{2}{|c|}{3} & \multicolumn{2}{|c|}{4} \\
\hline & Center & Frontier & Center & Frontier & Center & Frontier \\
\hline Gender (male) & $-0,049$ & $-0,067$ & $-0,045$ & $-0,064$ & $-0,046$ & $-0,069$ \\
\hline Age & $-0,727 * * *$ & $-0,104 * * *$ & $-0,725 * * *$ & $-0,099 * * *$ & $-0,735 * * *$ & $-0,100 * * *$ \\
\hline Age squared & $0,642 * * *$ & 0,045 & $0,639 * * *$ & 0,042 & $0,649 * * *$ & 0,040 \\
\hline Children & $-0,053$ & $-0,044^{*}$ & $-0,050$ & $-0,042$ & $-0,048$ & $-0,045^{* *}$ \\
\hline Religious person & $0,068 *$ & 0,024 & $0,069 *$ & 0,029 & $0,068 *$ & 0,023 \\
\hline Locus of control & $0,133 * * *$ & $0,040 *$ & $0,131 * * *$ & $0,040 *$ & $0,133 * * *$ & $0,043 * *$ \\
\hline Income group & $0,257 * * *$ & $0,245 * * *$ & $0,263 * * *$ & $0,248 * * *$ & $0,261 * * *$ & $0,242 * * *$ \\
\hline Type of settlement & $-0,053$ & $-0,024$ & $-0,053$ & $-0,025$ & $-0,051$ & $-0,022$ \\
\hline National indentity & 0,055 & $0,077 * * *$ & & & & \\
\hline Regional identity & & & $-0,034$ & $-0,022$ & & \\
\hline Local identity & & & & & $-0,025$ & $-0,066^{* * *}$ \\
\hline Social cohesion & $0,089 * *$ & $0,189 * * *$ & $0,092 * *$ & $0,190 * * *$ & $0,091 * *$ & $0,043 * *$ \\
\hline $\mathrm{R}^{2}$ & 0,161 & 0,136 & 0,159 & 0,131 & 0,159 & 0,135 \\
\hline Adj. $R^{2}$ & 0,152 & 0,133 & 0,150 & 0,128 & 0,149 & 0,132 \\
\hline $\mathrm{N}$ & 886 & 3112 & 886 & 3112 & 886 & 3112 \\
\hline
\end{tabular}

Standardized regression coefficients. Significance levels: ${ }^{*} p<.05,{ }^{*} p<.01, * * * p<.001$ (twotailed)

\begin{tabular}{|c|c|c|c|c|c|c|}
\hline \multirow{2}{*}{$\begin{array}{l}\text { b) Life satisfaction } \\
\text { (dependent variable) }\end{array}$} & \multicolumn{2}{|c|}{ Model 4} & \multicolumn{2}{|c|}{ Model 5} & \multicolumn{2}{|c|}{ Model 6} \\
\hline & Center & Frontier & Center & Frontier & Center & Frontier \\
\hline Gender (male) & $-0,055$ & $-0,067$ & $-0,052$ & $-0,063 * * *$ & $-0,052$ & $-0,067$ \\
\hline Age & $-0,569 * *$ & $-0,107 * * *$ & $-0,567 * *$ & $-0,104 * * *$ & $-0,575^{* * *}$ & $-0,103 * * *$ \\
\hline Age squared & $0,457 * *$ & 0,042 & $0,453 * *$ & 0,041 & $0,462 * *$ & 0,039 \\
\hline Children & $-0,038$ & $-0,036 *$ & $-0,037$ & $-0,034^{*}$ & $-0,035$ & $-0,037^{*}$ \\
\hline Religious person & $0,073 *$ & 0,015 & $0,067 *$ & 0,020 & $0,068^{*}$ & 0,023 \\
\hline Locus of control & $0,090 * *$ & $0,042 * *$ & $0,089 * *$ & $0,042 * *$ & $0,090 * *$ & $0,044 * *$ \\
\hline Income group & $0,229 * * *$ & $0,192 * * *$ & $0,233 * * *$ & $0,196 * * *$ & $0,231 * * *$ & $0,190 * * *$ \\
\hline Type of settlement & $-0,041$ & $-0,017$ & $-0,042$ & $-0,018$ & $-0,040$ & $-0,015$ \\
\hline National indentity & 0,044 & $0,071 * * *$ & & & & \\
\hline Regional identity & & & $-0,033$ & $-0,039 *$ & & \\
\hline Local identity & & & & & $-0,020$ & $-0,048 * *$ \\
\hline Social cohesion & 0,033 & $0,140 * * *$ & 0,035 & $0,141 * * *$ & $\mathbf{0 , 0 3 4}$ & $0,142 * * *$ \\
\hline $\begin{array}{l}\text { Satisfaction with the sit- } \\
\text { uation in the region }\end{array}$ & $0,283 * * *$ & $0,292 * * *$ & $0,283 * * *$ & $0,296 * * *$ & $0,283 * * *$ & $0,291 * * *$ \\
\hline $\mathrm{R}^{2}$ & 0,231 & 0,217 & 0,230 & 0,213 & 0,229 & 0,214 \\
\hline Adj. $\mathrm{R}^{2}$ & 0,221 & 0,214 & 0,220 & 0,210 & 0,219 & 0,211 \\
\hline $\mathrm{n}$ & 872 & 3056 & 872 & 3056 & 872 & 3056 \\
\hline
\end{tabular}

Standardized regression coefficients. Significance levels: $* p<.05, * * p<.01, * * * p<.001$ (twotailed) 
Continued Table 2

\begin{tabular}{|c|c|c|c|c|c|c|}
\hline 1 & \multicolumn{2}{|c|}{2} & \multicolumn{2}{|c|}{3} & \multicolumn{2}{|c|}{4} \\
\hline c) Life satisfaction & \multicolumn{2}{|c|}{ Model 7} & \multicolumn{2}{|c|}{ Model 8} & \multicolumn{2}{|c|}{ Model 9} \\
\hline & Center & Frontier & Center & Frontier & Center & Frontier \\
\hline Gender (male) & $-0,052$ & $-0,043$ & $-0,048$ & $-0,038$ & $-0,050$ & $-0,043^{* *}$ \\
\hline Age & $-0,539 * *$ & $-0,059 * *$ & $-0,532 * *$ & $-0,055^{*}$ & $-0,548 * *$ & $-0,054 *$ \\
\hline Age squared & $0,450 *$ & 0,025 & $0,400 *$ & 0,023 & $0,458 *$ & 0,021 \\
\hline Children & $-0,036$ & $-0,030$ & $-0,036$ & $-0,028$ & $-0,032$ & $-0,031$ \\
\hline Religious person & $0,068 *$ & $-0,004$ & $0,069^{*}$ & 0,002 & $0,067 *$ & $-0,004$ \\
\hline Locus of control & $0,112 * *$ & $0,052 * *$ & $0,111 * *$ & $0,053 * *$ & $0,112 * *$ & $0,134 * * *$ \\
\hline Economic optimism & $0,183 * * *$ & $\mathbf{0}, 330 * * *$ & $0,186 * * *$ & $0,329 * * *$ & $0,184 * * *$ & $0,327 * * *$ \\
\hline Type of settlement & $-0,044$ & 0,017 & $-0,045$ & 0,016 & $-0,043$ & 0,019 \\
\hline National indentity & 0,058 & $0,085 * * *$ & & & & \\
\hline Regional identity & & & $-0,045$ & $-0,046 * *$ & & \\
\hline Local identity & & & & & $-0,030$ & $-0,058 * * *$ \\
\hline Social cohesion & 0,050 & $0,133 * * *$ & 0,054 & $0,134 * * *$ & 0,052 & $0,134 * * *$ \\
\hline $\begin{array}{l}\text { Satisfaction with the sit- } \\
\text { uation in the region }\end{array}$ & $0,274 * * *$ & $0,217 * * *$ & $0,274 * * *$ & $0,223 * * *$ & $0,275 * * *$ & $0,217 * * *$ \\
\hline $\mathrm{R}^{2}$ & 0,221 & 0,271 & 0,219 & 0,266 & 0,218 & 0,267 \\
\hline Adj. $\mathrm{R}^{2}$ & 0,209 & 0,268 & 0,208 & 0,263 & 0,207 & 0,265 \\
\hline $\mathrm{n}$ & 766 & 2882 & 766 & 2882 & 766 & 2882 \\
\hline
\end{tabular}

Standardized regression coefficients. Significance levels: ${ }^{*} p<.05, * * p<.01, * * * p<.001$ (twotailed)

\begin{tabular}{|c|c|c|c|c|c|c|}
\hline \multirow{2}{*}{$\begin{array}{l}\text { d) Life satisfaction } \\
\text { (dependent variable) }\end{array}$} & \multicolumn{2}{|c|}{ Model 10} & \multicolumn{2}{|c|}{ Model 11} & \multicolumn{2}{|c|}{ Model 12} \\
\hline & Center & Frontier & Center & Frontier & Center & Frontier \\
\hline Gender (male) & $-0,050$ & $-0,044$ & $-0,045$ & $-0,040 *$ & $-0,047$ & $-0,045^{*}$ \\
\hline Age & $-0,594 * *$ & $-0,062 * *$ & $-0,586 * *$ & $-0,059 *$ & $-0,605 * *$ & $-0,057 *$ \\
\hline Age squared & $0,519 *$ & 0,026 & $0,508 *$ & 0,025 & $0,529 * *$ & 0,022 \\
\hline Children & $-0,047$ & $-0,032$ & $-0,048$ & $-0,030$ & $-0,044$ & $-0,033$ \\
\hline Religious person & 0,052 & $-0,017$ & 0,053 & $-0,011$ & 0,051 & $-0,019$ \\
\hline Locus of control & $0,125 * * *$ & $0,056 * *$ & $0,125 * * *$ & $0,057 * *$ & $0,125 * * *$ & $0,057 * * *$ \\
\hline Economic optimism & $0,186^{* * *}$ & $0,328 * * *$ & $0,189 * * *$ & $0,326 * * *$ & $0,187 * * *$ & $0,324 * * *$ \\
\hline Type of settlement & $-0,041$ & 0,025 & $-0,041$ & 0,024 & $-0,039$ & 0,027 \\
\hline National indentity & $0,065^{*}$ & $0,078 * * *$ & & & & \\
\hline Regional identity & & & $-0,053$ & $-0,041 * *$ & & \\
\hline Local identity & & & & & $-0,037$ & $-0,058 * * *$ \\
\hline Social cohesion & 0,059 & $0,122 * * *$ & 0,064 & $0,122 * * *$ & 0,061 & $0,122 * * *$ \\
\hline $\begin{array}{l}\text { Satisfaction with the sit- } \\
\text { uation in the country }\end{array}$ & $0,243 * * *$ & $0,232 * * *$ & $0,243 * * *$ & $\mathbf{0 , 2 3 8} * * *$ & $0,244 * * *$ & $0,235 * * *$ \\
\hline $\mathrm{R}^{2}$ & 0,208 & 0,272 & 0,207 & 0,268 & 0,205 & 0,270 \\
\hline Adj. $\mathrm{R}^{2}$ & 0,196 & 0,269 & 0,195 & 0,265 & 0,194 & 0,267 \\
\hline $\mathrm{n}$ & 761 & 2826 & 761 & 2826 & 761 & 2826 \\
\hline
\end{tabular}


affairs in the country (models 10-12) are equally significant and influential everywhere.

Attention is drawn to the age factor, which is significant and stable in all models for the regions of the center, but not in the sample of the frontier: younger respondents are more satisfied with their lives in the regions of the center. However, the value of this factor is reduced by the introduction of satisfaction with the situation in the region or country into the model. Since the models in the table present standardized regression coefficients that allow us to estimate the relative contribution of each independent variable to the model, it can be concluded that the age factor is the most influential in all models explaining life satisfaction.

The expected influence of the factor of income, which represents here the attribution of oneself to the income group according to consumer possibilities. This primary indicator of living standards exerts its influence equally in the frontier and the center. In models 7-12, the income group predictor was replaced by the factor of economic optimism, since they correlate with each other. This factor also has the maximum level of statistical significance, but its contribution is not the same in the two groups of regions; in the frontier, it is twice as influential in terms of life satisfaction as in the center. Among the universal predictors of life satisfaction that are relevant both to frontier and region, it is also a locus of control. However, its weight in models for the regions of the center is twice as high.

The respondent's gender and place of residence were found to be insignificant factors in both samples. The influence of having children in the family has a feeble negative effect on life satisfaction only in the regions of the frontier. It disappears when the factor of economic optimism is included in the model. On the contrary, the factor of an individual's religiosity shows a weak positive relationship with life satisfaction only in the regions of the center of the country. It also disappears when the predictor of satisfaction with the situation in the country is added to the model. Finally, the classical for the frontier theory socio-cultural trait presented as an indicator of social cohesion showed its influence in all models for the frontier sample; in the regions of the center, it showed weak significance only in models $1-3$, before the inclusion of predictors of satisfaction with life in the region and the country.

\section{Conclusion}

It has become commonplace in social research to speak of a high degree of territorial heterogeneity and socio-cultural diversity in Russia. This diversity is viewed both in an "optimistic" way as a country's development potential and in a "challenging" one, as a possible source of division and even separatism. The issue of the optimal level of regional differentiation in Russia is up to date, which, on the one hand, would support the development and active interregional "economic division," and on the other hand, would preserve the political and economic unity of the country. The frontier location of the region has an impact on various socio-cultural and socio-political features of its communities, thus shaping the specific territorial-civic identity of people living on the front lines of Russia. For instance, in the frontier regions, the cross-border mobility of the population is higher, leading to the familiarity with the social life and economic conditions of neighboring countries. This awareness determines that the population of the frontiers is more loyal and open to cultural exchange with the border states. Such features of the mass consciousness and social practice of the inhabitants of the frontier regions, presumably, are significant factors in the formation of a special territorial, social, and political identity. According to the descriptive analysis of the regional survey data, the frontier and core Russian regions differ slightly in terms of most of the analyzed indicators of social well-being. The residents of frontier regions are relatively more likely to express satisfaction with the state of affairs in their region than the residents of control regions. The studied regions turned out to be rather heterogeneous by territorial identity; however, some specificity has to be mentioned. National identity prevails in two frontier regions, Kaliningrad and Murmansk regions, and one control region, Chuvash Republic. Regional identity is relatively more salient in the Primorsky Territory and 
especially in the Crimea. For the first region, the geographical remoteness of the Far Easter from central Russia, the feeling of being "on the edge of the earth" intensify the awareness of belonging to the region of residence. For the latter, the high level of regional identity may be explained by the relatively recent entry of Crimea into Russia and the change of citizenship, which entails a change of territorial identity; thus the identification with Crimea is of an adaptive nature and allows maintaining a sense of stability against the background of ongoing socio-political transformations. Representing the Russian core Kostroma region has the highest level of local identity: probably, many Kostroma residents, despite their belonging to the Central Federal District, also feel abandoned by the "center", which is also confirmed by the low satisfaction with affairs in the region.

Nevertheless, the "frontier" specifics in territorial identity was revealed in the regression modeling. Correspondingly with hypothesis one, by means of ordinary least squares model, we find that concerning life satisfaction, the attitudes of frontier and central populations are influenced by different territorial social identities that are also negatively correlated with each other. In line with hypothesis two, frontier inhabitants tend to be more satisfied with life is they associate themselves with the country as the whole, but not with their region or place of residence. However, this proposition did not work for the popula- tion of the core regions. On the contrary, in the central regions, the territorial identity of any kind does not play any role in explaining its inhabitants' life satisfaction, the primary focus is on the factors of socio-economic, socio-demographic, psychological and cultural nature, such as income, economic optimism, age, locus of control and religiosity. In its turn, social ties and feeling of cohesion between the surrounding people contribute to the subjective well-being of the frontier residents. Finally, hypothesis three confirmed for both groups of the regional samples, as far as the assessment of the state of affairs in the region, and the country showed a positive effect on life satisfaction in all models.

Additionally, the study of attitudes and well-being of the population in the frontier regions of the country under the conditions of current geopolitical competition and challenging foreign affairs situation might contribute to the more profound understanding of modern Russian society. In the course of such work, it becomes possible to conduct a sociological comparison of the frontier and internal regions of the country, in the context of the theory of the frontier. This, in turn, contributes to the theoretical and methodological tools of studies of the border areas. The results of the study seem to be important for the public administration in charge of the socio-economic development of the country, for the specification of a strategy for the development of the regions of the Russian frontier.

\section{References}

DeNeve, K.M, Cooper, H. (1998). The Happy Personality: a Meta-analysis of 137 Personality Traits and Subjective Well-being. In Psychological Bulletin, 124(2), 197-229. DOI: 10.1037/00332909.124.2.197

Diener, E., Diener, M., Diener, C. (1995). Factors Predicting the Subjective Well-being of Nations. In Journal of Personality and Social Psychology, 69(5), 851-864. DOI: http://dx.doi.org/10.1037/00223514.69.5.851

Diener, E., Suh, E.M., Lucas, R.E., Smith, H.L. (1999). Subjective Well-being: Three Decades of Progress. In Psychological Bulletin, 125 (2): 276-302. DOI:10.1037/0033-2909.125.2.276

Dolan, P., Peasgood, T., White, M. (2008). Do We Really Know What Makes Us Happy? A Review of the Economic Literature on the Factors Associated with Subjective Well-being. In Journal of Economic Psychology, 29, 94-122. DOI:10.1016/j.joep.2007.09.001

Dovidio, J.F., Gaertner, S.L., Pearson, A.R. and Riek, B.M. (2005). Social Identities and Social Context: Social Attitudes and Personal Well-Being. In Thye, S.R. and Lawler, E.J. (Ed.) Social Identification 
in Groups (Advances in Group Processes, Vol. 22), Emerald Group Publishing Limited, Bingley, 231-260. DOI: https://doi.org/10.1016/S0882-6145(05)22009-X

Easterlin, R.A. (1974). Does Economic Growth Improve the Human Lot?: Some Empirical Evidence. In P.A. David \& W.R. Levin (Eds.) Nations and households in economic growth, pp. 98-125. Palo Alto, CA: Stanford University Press.

Foa, R.S., Nemirovskaya, A.V. (2019). Frontier Settlement and the Spatial Variation of Civic Institutions. In Political Geography, 73, 112-122. DOI: https://doi.org/10.1016/j.polgeo.2019.05.013

Guzhavina, T.A. (2019). Social Capital of the Urban Community: State and Dynamics in the Industrialized City. In Siberian Socium, 3(4), 38-52. DOI: 10.21684/2587-8484-2019-3-4-38-52.

Imamura, M. (2015). Rethinking frontier and frontier studies. In Political Geography, 45 (96-97). DOI: http://dx.doi.org/10.1016/j.polgeo.2014.09.014

Inglehart, R. (1990). Culture Shift in Advanced Industrial Societies. Princeton University Press, Princeton, 1990.504 p.

Klein, C. (2013). Social Capital or Social Cohesion: What Matters For Subjective Well-Being? In Social Indicators Research, 110, 891-911. DOI: https://doi.org/10.1007/s11205-011-9963-x

Maksimova, S.G., Noyanzina, O.E., Goncharova, N.P., Omelchenko, D.A., Avdeeva, G.S. (2015). Usloviya formirovaniya rossiyskoy natsional'noy identichnosti naseleniya sovremennoy Rossii (na primere issledovaniya $\mathrm{v}$ Altayskom kraye [The conditions for the formation of the Russian national identity of the population of modern Russia (on an example of research in the Altai Territory)]. In Uchonyye zapiski ZabGU. Seriya: Filosofiya, sotsiologiya, kul'turologiya, sotsial'naya rabota [Scientific Notes of ZabSU. Series: Philosophy, Sociology, Cultural Studies, Social Work], 4 (63), 150-156.

Maksimova, S.G., Morkovkina, A.G. (2017). The Image of Russia in Contemporary Representations by the Population of the Border Regions. In Siberian Socium, 1(1), 57-61. DOI: 10.21684/2587-8484-2017$1-1-57-61$

Maslow, A.H. (1943). A Theory of Human Motivation. In Psychological Review, 50(4), 370-396.

Nemirovsky, V.G. (2013). Mass Consciousness of Siberia Region Inhabitants: Ideas of Selves and of Russia. In Sotsiologicheskie Issledovaniya, 4, 54-60. DOI: WOS:000319891000006

Pohl, J. (2001). Regional Identity. In International Encyclopedia of the Social \& Behavioral Sciences, 12917-12922. DOI: https://doi.org/10.1016/B0-08-043076-7/02488-8

Reeskens. T., Wright, M. (2010). Subjective Well-being and National Satisfaction: Taking Seriously the 'Proud of What?" Question. In Psychological Science, 22, 1460-1462. DOI: DOI: 10.1177/0956797611419673

Tay, L., Li, M., Myers, D., Diener, E. (2014). Religiosity and Subjective Well-Being: An International Perspective. In Kim-Prieto C. (eds) Religion and Spirituality Across Cultures. Cross-Cultural Advancements in Positive Psychology, 9, Springer, Dordrecht, 163-175. DOI: https://doi.org/10.1007/978-94-0178950-9 9

Turner, Frederick J. (1920). The Frontier in American History. New York, NY: Henry Holt.

Veenhoven, R. (1991). Is Happiness Relative? In Social Indicators Research, 24(1), 1-34. DOI: https:// doi.org/10.1007/BF00292648 


\title{
Субъективное благополучие населения и конфликт социальных идентичностей в регионах российского фронтира
}

\author{
A.В. Немировская \\ Национальный исследовательский университет «Высшая школа экономики» \\ Российская Федерация, Москва
}

\begin{abstract}
Аннотация. В статье представлено исследование различных показателей субъективного благополучия и территориальной социальной идентичности во фронтирных и центральных регионах России. Предполагается, что фронтирная история заселения и пограничное расположение регионов оказывают влияние на различные социокультурные и социально-политические особенности региональных сообществ, формируя тем самым специфические территориальные социальные идентичности людей, живущих в рубежных регионах России. Эти идентичности могут находиться в противоречивых, конфликтных отношениях, особенно когда они рассматриваются как фактор формирования определенных общественных установок и настроений, в частности удовлетворенности жизнью. На основе опросов в четырех фронтирных, или приграничных, и двух центральных, или коренных, регионах, проведенных в 2016 г. (всего n респондентов $=5000)$, в статье представлена объясняющая модель удовлетворенности жизнью в сравнительном аспекте. В анализе рассматриваются факторы социально-экономического, социальнодемографического, психологического, аттитюдинального и культурного характера. Выявлено различное влияние территориальных социальных идентичностей на удовлетворенность жизнью во фронтирных и центральных регионах. Для обеих групп региональных выборок оценка состояния дел в регионе, а также в стране продемонстрировала устойчивое положительное влияние на удовлетворенность жизнью, так же как и факторы локуса контроля, группы доходов по самооценке и экономического оптимизма. Предиктор социальной сплоченности оказался значимым только для фронтирных регионов России в соответствии с классическими концепциями фронтира. В то же время факторы возраста и религиозности предсказывали удовлетворенность жизнью только в центральных регионах. Данное исследование способствует изучению приграничных и фронтирных территорий, а также региональной специфики регионов России как обширной и неоднородной с точки зрения социокультурного и социально-экономического деления страны.
\end{abstract}

Ключевые слова: субъективное благополучие, удовлетворенность жизнью, территориальная идентичность, регионы России, фронтир.

Исследование выполнено за счет гранта Российского научного фонда: проект № 18-18-00341 «Ценностная трансформация и субъективное качество жизни: региональная перспектива». В исследовании использованы эмпирические материалы исследовательского проекта «Российский фронтир: гражданская идентичность на передовом рубеже страны», выполненного АНО «Социологическая мастерская Задорина» (Исследовательская группа ЦИРКОН) при участии автора статьи на средства целевого финансирования, выделенные Некоммерческим фондом «Институт социально-экономических и политических исследований».

Научная специальность: 22.00.00 - социологические науки. 